超音波ドップラー法による椎骨・総頸動脈血流測定法

一健常成人を対象として一

和田 佳郎・藤田 信哉・康勲

上田 隆志・松永喬

\title{
Measurement of the Vertebral and Common Carotid Arterial Hemo- dynamics of Normal Subjects by Ultrasonic Doppler Method
}

\author{
Yoshiro Wada, Nobuya Fujita, Isao Koh, Takashi Ueda and Takashi Matsunaga \\ (Nara Medical University)
}

This study was performed to clarify the hemodynamic of vertebral and common carotid arteries of normal subjects by ultrasonic doppler method. Subjects were 51 in all, i.e., 41 males and 10 females, between 22 and 64 years old.

For the vertebral artery, mean blood velocity (BV) was $9.4 \pm 3.5 \mathrm{~cm} / \mathrm{s}$, mean blood flow volume $(\mathrm{BF})$ was $1.6 \pm 0.6 \mathrm{ml} / \mathrm{s}$ and mean vessel diameter (VD) was $4.6 \pm 0.5 \mathrm{~mm}$. On the other hand, for the common carotid arteries, BV was $31.5 \pm 5.2 \mathrm{~cm} / \mathrm{s}$, BF was $14.0 \pm 3.2 \mathrm{ml} / \mathrm{s}$ and VD was $7.5 \pm 0.6 \mathrm{~mm}$. BV of the vertebral arteries increased in the elderly, whereas BV of the common carotid arteries decreased in the elderly.

Key words: ultrasonic doppler method, vertebral artery, common carotid artery, hemodynamics

はじめに

耳鼻咽喉科外来においてめまいを主訴とする 患者数は年々増加傾向にあり, 特に原因不明の めまい患者のしめる割合は大きいい，その中に は自律神経機能異常や循環障害, 特に椎骨脳底 動脈系の循環障害が関係するめまいが数多く含 まれていると考兄られている2) 6). 我々も従来 より椎骨動脈系の循環障害がめまい疾患と関係 があると考え, 比較的容易かつ安全な椎骨動脈 IfI流測定法である超音波ドップラー法78) を， めまい疾患の補助診断として用いてきた。しか しこの測定法は間接的な測定法であるが故に, 正常值の特徵をよく知っておくことが大切であ
る。そこで今回，健常成人の椎骨動脈のみなら ず総頸動脈にも超音波ドップラー法を施行し， 血流動態を測定したので，その結果を報告する。

\section{対象及び方法}

めまい，難聴などの既往のない内耳機能正常 と思われる健常成人 51 人（男 41 人，女 10 人，2264藏, 平均年齢39.8墄）である（表 1 ）.

装置と原理

測定装置は超音波血流測定装置（林電気製， DFM-4500）を使用した。図 1 にブロックダイ ヤグラムを示す。測定の基本原理910) は，超音 波パルスエートラッキング法にて血管の後壁 ・前壁エコー間の距離すなわち血管径 $\mathrm{D}(\mathrm{t})$ を 
求め, それから血管断面積 $\mathrm{S}(\mathrm{t})$ を算出する. 次に一送波二受波超音波ドップラー法により血 流速度 $\mathrm{V}(\mathrm{t})$ を求め, 次式によって血流量 $\mathrm{Q}(\mathrm{t})$ を求める。

$$
\mathrm{Q}(\mathrm{t})=\mathrm{V}(\mathrm{t}) \times \pi(\mathrm{D}(\mathrm{t}) / 2)^{2}=\mathrm{V}(\mathrm{t}) \times \mathrm{S}(\mathrm{t}) \cdots \cdots \cdots 1
$$
心電図 QRS の立ち上がりを trigger とし，血 流速度, 血流量, 血管径の 5-15回の加算平均 を記録した。

測定方法

被験者をベット上仰臥位にし，両足右手に心 電図の電極を装着し, 安静状態にて測定を開始 した.

総頸動脈の測定は前頸部を軽く伸展させ総頸動 脈分岐部より $1-2$ 横指心臓側にゼリ一をつけ たプローブを軽く圧着し，ドップラー音が最大 で血管壁エコー鮮明かつ振幅最大になる条件で 測定した. 椎骨動脈の測定は前頸部を軽く反対 側に向かせ頸椎横突起を触診で探り, 乳様突起 より 1-2 横指下方, 1 横指後方の第 1 -第 2 あ

表 1 健常成人の年龄分布（人数）

\begin{tabular}{c|c|c|c}
\hline \hline 年啮 & 男 性 & 女 性 & 計 \\
\hline $20-29$ & 16 & 3 & 19 \\
$30-39$ & 7 & 1 & 8 \\
$40-49$ & 6 & 1 & 7 \\
$50-59$ & 5 & 5 & 10 \\
$60-69$ & 7 & 0 & 7 \\
\hline 計 & 41 & 10 & 51
\end{tabular}

るいは第 2 -第 3 横突起間と思われる部位にゼ リーをつけたプローブを軽く环着し，ドップ ラー音が最大になる条件で測定した，椎骨動脈 は後頭動脈とまぎらわしい場合が多く，同側の 総頸動脈を圧迫してドップラー音が減弱せず, 測定部位を触診して大きな拍動を認めなければ 椎骨動脈と同定した。

測定項目

椎骨動脈・総頸動脈の血流速度, 血流量, 血 管径を測定し，その左右差，性差，加齢による 変化を検討した。なお左右差は次式によって求 める左右差指数で表した。

$$
\text { 左右差 }=\mid(\text { 右一左 }) /(\text { 右 }+ \text { 左 }) \mid \times 100 \%
$$

\section{結果}

\section{1. 椎骨・総頸動脈の血流測定值}

表 2 は健常成人 51 人の椎骨・総頸動脈におけ る平均血流速度, 血流量, 血管径である. 表 3 は左右別々の椎骨・総頸動脈における血流速度, 血流量, 血管径と, 椎骨動脈血流速度の左右差 指数と, 総頸動脈の血流速度, 血流量, 血管径 の左右差指数である. 椎骨動脈は総頸動脈に比 して血流速度で約 $1 / 3$ ，血流量で約 $1 / 9$ であっ た。

な挆被験者によって椎骨動脈血管壁エコーが 不鮮明すなわち椎骨動脈血管径の測定が確実で ない場合が少なくなく，その場合 1 の式からわ かるように血流量の值も不確実になるため, 椎 骨動脈の血流量と血管径に関しては以下の分析 を行わなかった。

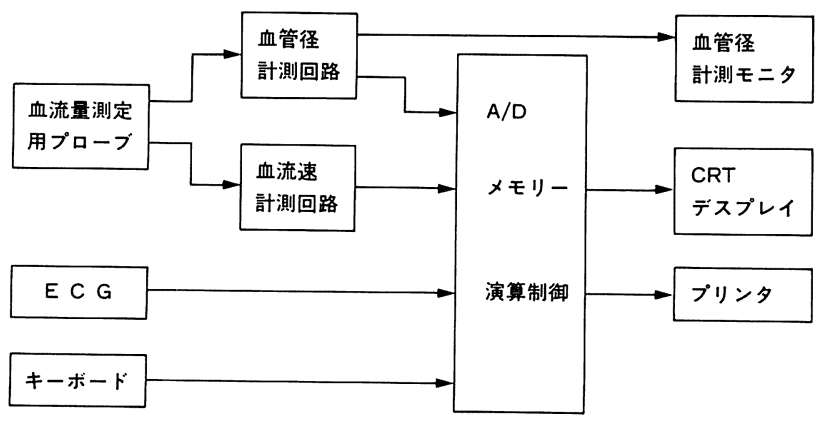

図1ブロックダイヤグラム 
2. 左右差

椎骨動脈血流速度は左が右よりやや速いが統 計学的な有意差はなかった（表 3 参照）。総頸 動脈は血流速度, 血流量, 血管径とも珤とんど 左右差は認められなかった。血流速度の左右差 指数の平均, 標準偏差とも椎骨動脈が総頸動脈 に比較して大きかった。

3. 性 差

椎骨動脈血流速度は女性が男性よりやや速く， 総頸動脈血流速度は逆に男性が女性よりやや速 いが，共に有意差はなかった（表 4 ）。しかし 総頸動脈血流量，血管径は左右とも有意（ $\mathrm{p}<$ 0.01）に男性の值が大きかった。 I血流速度左右 差指数は，椎骨動脈は男性が女性よりやや值が 大きいものの有意差はなく，総頸動脈は性差は みられなかった。また総頸動脈の血流量左右差 指数には性差はみられなかったが，血管径左在 差指数は有意（ $\mathrm{p}<0.05 ）$ に男性が大きかった。

4. 加齢による変化

健常成人の椎骨 - 総頸動脈102本について加

表 2 健常成人 51 人（男 41 人，女 10 人，平均 39.8 歳，22-64歳）に拈ける椎骨・総頸動脈血 流（平均）

\begin{tabular}{c|c|c}
\hline \hline 動 脈 & 椎 骨動脈 & 総頸動脈 \\
\hline 血流速度 & $9.4 \pm 3.5 \mathrm{~cm} / \mathrm{s}$ & $31.5 \pm 5.2 \mathrm{~cm} / \mathrm{s}$ \\
血 流 量 & $1.6 \pm 0.6 \mathrm{ml} / \mathrm{s}$ & $14.0 \pm 3.2 \mathrm{ml} / \mathrm{s}$ \\
血 管 径 & $4.6 \pm 0.5 \mathrm{~mm}$ & $7.5 \pm 0.6 \mathrm{~mm}$
\end{tabular}

(mean \pm S.D.)
齢による血流の変化を検討する目的で, 各測定 値と年䶜との相関を調べた（図 2 ）。椎骨動脈 III流速度は加齢と共にやや速くなるものの有意 な相関はないが，それとは逆に総頸動脈血流速 度は加齢と共に遅くなり, 有意 $(\mathrm{p}<0.01)$ な負 の相関を示した。 また性差のみられた総頸動脈 血流量および血管径を男女別々にみると, 男女 とも総頸動脈血流量と年齢にはほとんど相関は みられないが，血管径は加蹂と共に太くなり，

表 4 椎骨·総頸動脈血流の性差

\begin{tabular}{|c|c|c|c|c|}
\hline & 測 定 項 目 & & $\begin{array}{c}\text { 男 } \mathrm{N}=41 \\
38.9 \text { 歳 }\end{array}$ & $\begin{array}{c}\text { 女 } \mathrm{N}=10 \\
43.3 \text { 歳 }\end{array}$ \\
\hline & 血流速度 & 右 & $8.8 \pm 3.7$ & $10.0 \pm 3.2$ \\
\hline 监 & $\mathrm{cm} / \mathrm{s}$ & 左 & $9.5 \pm 3.6$ & $10.5 \pm 2.6$ \\
\hline 勤 & IfI流速度左 & & $17.3 \pm 14.0$ & $10.1 \pm 9.4$ \\
\hline & 血流速度 & 右 & $31.4 \pm 4.9$ & $29.7 \pm 6.6$ \\
\hline & $\mathrm{cm} / \mathrm{s}$ & 左 & $32.0 \pm 4.9$ & $31.3 \pm 5.8$ \\
\hline 総 & IfII流速度左 & & $5.2 \pm 4.5$ & $5.3 \pm 7.2$ \\
\hline 頸 & 血 流 量 & 右 & $14.7 \pm 3.0-* *-$ & $11.4 \pm 1.9$ \\
\hline & & 左 & $14.6 \pm 3.4-* *-$ & $11.6 \pm 1.2$ \\
\hline 動 & IfIl 流量左 & & $5.5 \pm 4.5$ & $4.0 \pm 3.7$ \\
\hline 脈 & 血 管 径 & 右 & $7.6 \pm 0.7-* *-$ & $7.0 \pm 0.4$ \\
\hline & $\mathrm{mm}$ & 左 & $7.6 \pm 0.5-* *-$ & $6.9 \pm 0.4$ \\
\hline & 血管径左 & $\begin{array}{l}\text { 差 } \\
\%\end{array}$ & $2.7 \pm 2.1-*-$ & $1.3 \pm 1.4$ \\
\hline & -11 & . & $\begin{array}{l}\text { 吉 } \mid \times 100 \% \\
><0.05\end{array}$ & $a n \pm$ S.D.) \\
\hline
\end{tabular}

表 3 健常成人 51 人（男 41 人，女 10 人，平均 39.8 藏，22 64藏） にお壮る椎骨・総頸動脈血流（左右別）

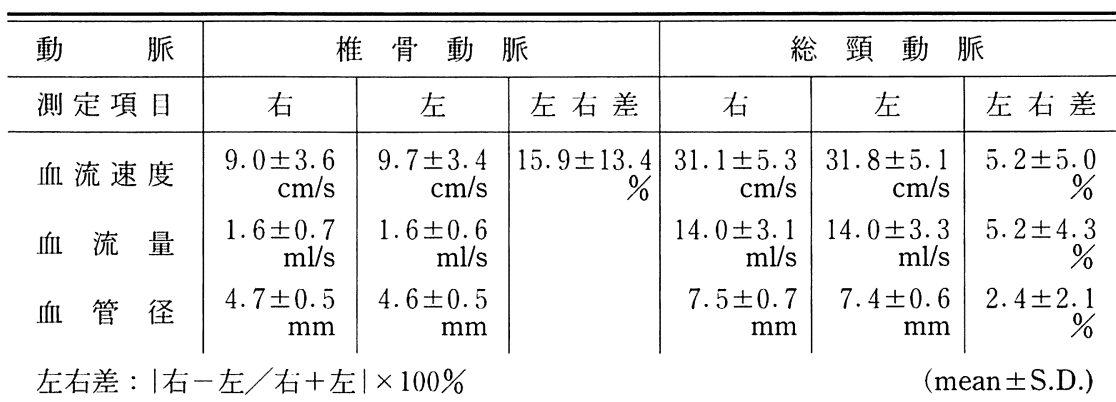


特に男性には有意（ $\mathrm{p}<0.01 ）$ な正の相関がみ られた．次に健常成人 51 人について加秢による 血流の左右差指数の変化をみると（図 3 ), い ずれの測定值も年歯と有意な相関は認められな かった。

\section{考察}

椎骨動脈は鎖骨下動脈から分岐した後, 頸椎 横突起孔内を上行し, 頭蓋内に入って脳底動脈 となる。したがって超音波ドップラー法による 椎骨動脈の測定は限られた横突起間で施行しな ければならない，血流速度の測定は後頭動脈と の鑑別にさえ注意すれば確実に行えるが，血管 径の測定は横突起や周囲組織との解剖学的な関 係で困難な場合が少なくない１の式からわか るよらに，血流量を求めるには血管径の值が必 要であり, 今回は不確実な椎骨動脈の血管径及 び血流量に関しての詳細な検討は行わなかった。
また超音波ドップラー法は間接的な血流測定法 であるため，その再現性を検討したところ，血 流速度については椎骨動脈で平均 $\pm 5.6 \%$, 総 頸動脈で士6.2\%の測定䛊差がみられた。以上 は現時点での超音波ドップラー法による椎骨・ 総頸動脈血流測定法の限界であるとも言える.

左右 2 本の椎骨動脈および総頸動脈は並列流 体管であると同時に，その 1 本 1 本に注目すれ ば直列流体管でもある。単純な並列流体管は管 径に左右差があれば太い方が流速は速くなるが， 逆に直列流体管は管径に細い部分があればその 部分で流速は速くなる11)。ささら流体管の弾性 や流体の粘性，また実際には側枝や末梢血管抵 抗の影響も大きく，血流速度の解釈は簡単には できないが，可能な範囲で今回の測定結果につ いて考察を試みた。

\section{椎骨動脈血流速度左右差}

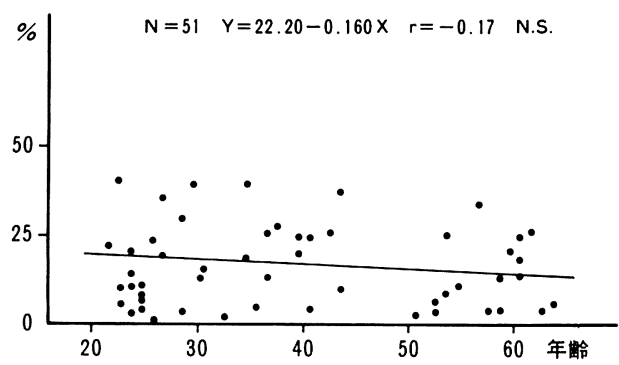

総頸動脈血流量左右差

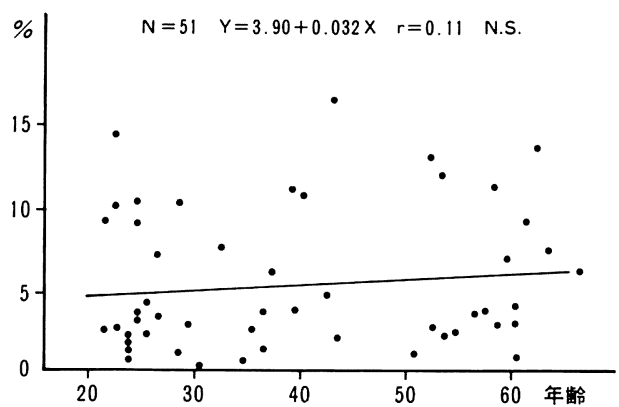

\section{総影钦脈血流速度左右差}

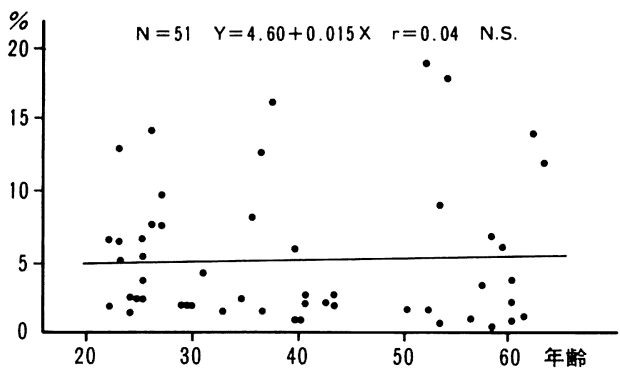

図 2 椎骨・総頸動脈I血流と年齡の相関

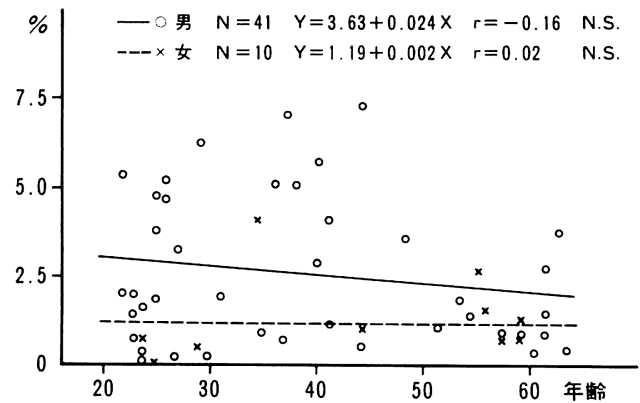


1. 正常值について

超音波ドップラー法による健常成人の椎骨・ 総頸動脈血流の測定值は, 報告者によってその 值が少しずつ異なっている12)13)。これは測定装 置や測定方法, 測定部位, あるいは被験者の測 定体位の違い等によるものであろう。我々の測 定結果は例えば松永ら ${ }^{14)}$ の值に比べてやや大 きいものの，それぞれの項目がほぼ同じ割合で 大きく，相対的な違いであると思われる.この ため超音波ドップラー法の正常值は各施設ごと に定める必要があり, 測定值の絶対値よりもむ しろ左右差や経時変化 ${ }^{15)}$ に臨床的意義がある と思われる。

2. 左右差について

総頸動脈血流には汪とんど左右差はないが， 椎骨動脈血流速度は有意差はない子のの右 9.0 $\mathrm{cm} / \mathrm{s}$, 左 $9.7 \mathrm{~cm} / \mathrm{s}$ と左の方が速い。 また左右

椎骨動脈血流速度

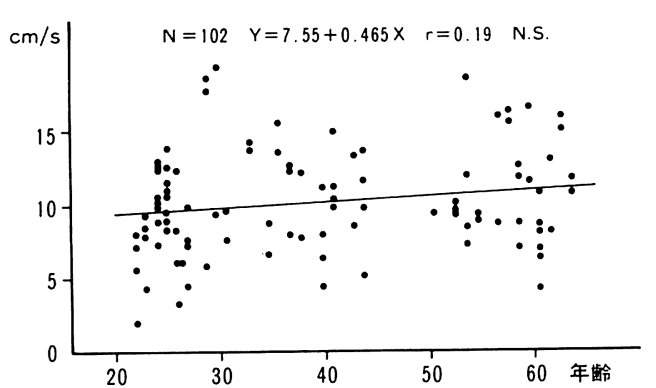

総頸動脈血流量

一男 $N=82 \quad Y=14.55+0.002 X \quad r=0.01 \quad$ N.S

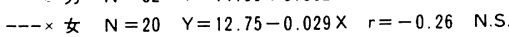

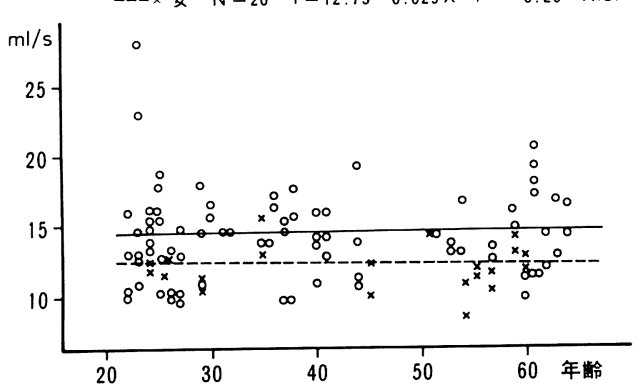

差指数の平均も椎骨動脈 $15.9 \%$, 総頸動脈 5.2 $\%$ と椎骨動脈がはるかに大きく，標準偏差も椎 骨動脈が大きい。一方亀山 ${ }^{16)}$ は60歳以上の老 年者剖検例165例の解剖学的検索より, 椎骨動 脈血管径の左右差著明なものは51例（31\%）飞 および，らち39例（24\%）では右が細かったと 報告している。これらの事実から椎骨動脈を単 純な並列流体管とみなせば，解剖学的に左が太 いため血流速度が速くなり，総頸動脈に比べて variation に富んでいるため左右差指数の平均 や標準偏差が大きくなったと理解することがで きる. したがって椎骨動脈血流速度の左右差が 存在する場合，正常範囲か病的左右差であるか といら判断は慎重に下さなくてはならない。

\section{3. 性差について}

総頸動脈に関しては，血流速度にはほとんど 性差はみられないにもかかわらず，血流量及び

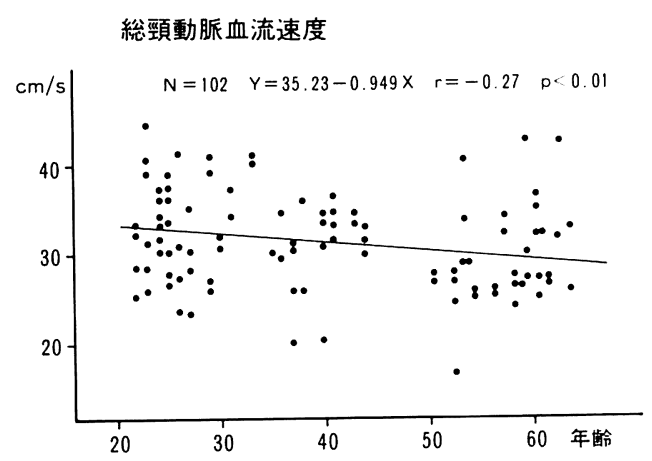

\section{総頸動脈血管径}

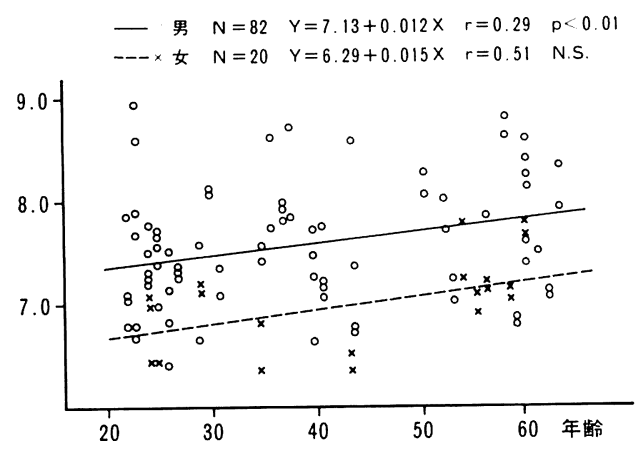

図 3 椎骨・ - 総頸動脈血流左右; 差指数と年略の相関 
血管径は共に男性が女性に比べ有意に值が大き い.これは 1 の式から男性の血管径が太いこと に起因するといらことがわかる．また血流量お よび血管径左右差指数も男性が女性に比べ大き く，これも男性の血管径の左右差が大きいこと に起因寸るものと思われる. 一方椎骨動脈血流 速度は有意差はないものの女性がやや速い。こ の理由はよくわからないが，女性の椎骨動脈血 管径が相対的に細いため, 血流速度が速くなっ たのではないかと推測できる。

4. 加龄による変化について

総頸動脈に関しては, 加齢と共に血流速度は 遅く，血管径は太くなるが，血流量には汪とん ど変化はみられなかった. 総頸動脈の血管径が 太くなるのは，加秢による動脈硬化によって血 管壁弾力繊維の断裂・減少が生じ血管が伸展し た結果であろら 17)18)。 またそれに総頸動脈の末 梢血管抵抗の増大が加わった結果, 血流速度が 遅くなったのであろう．そして血管径は太くな るが血流速度が遅くなったので, 相殺されて血 流量にはほとんど変化がみられなかったと推測 できる.しかし今回は64歳までしか対象にして おらず，澤井19) は60歳以上から総頸動脈血流 量は減少すると報告していることから，今後対 象をもら少し高齢にまで広げて検討する必要が あると思われた。一方, 椎骨動脈血流速度は年 歯との間に有意な相関関係はないもののやや速 くなる傾向がみられ, 総頸動脈とはまったく逆 の加齢変化を示すことは興味深く思われた。 た椎骨・総頸動脈血流の左右差指数と年齢との 間には有意な相関関係はみられなかったものの， 椎骨動脈血流速度左右差指数は減少, 総頸動脈 IfI流速度左右差指数は増加傾向と, やはり逆の 加齢変化を示した. 特に加齢と共に椎骨動脈血 流速度はやや速く, 椎骨動脈血流速度左右差指 数はやや小さくなるといら結果は, 後藤20) の 椎骨動脈血管径の左右差は若年者では大きいが, 加齢と共に動脈硬化が進み径が小さくなると左 右差が小さくなる方向に向から, といら解剖学 的な報告とよく一致する。いずれにせよ椎骨動
脈と総頸動脈とでは, その血流の加歯変化に明 らかな差が存在し, 総頸動脈は内頸と外頸動脈 に分岐するため厳密には脳循環を意味するとは 言えないが，このような加齢と共に増大する血 流動態の差がめまい発症の一要因であるかもし れない。

最近当教室では, static な血流測定法である DSA (digital subtraction angiography) ${ }^{2122)}$ と, 容易かつ安全で dynamic な測定法である超音 波ドップラー法を併用することにより, static, dynamic 両面からのより信頼性の高い血流障 害の診断を試みている23)。また脳底動脈や前・ 中・後大脳動脈等の頭蓋内動脈血流測定法であ る Transcranial Doppler24)25) が開発され，血流 障害診断のさらに飛躍的な進歩が望まれる.今 後超音波ドップラー法はその長所をいかして， めまい患者のスクリーニング検査や補助診断の みならず, 治療効果や薬剤の作用部位判定など, 幅広い利用が期待される.

おわりに

健常成人 51 人（男 41 人，女 10 人，22-64歳） を対象に，超音波ドップラー法によって椎骨・ 総頸動脈血流を測定し，以下の特徵および問題 点を考察した.

1. 測定結果は, 椎骨動脈については血流速 度 $9.4 \pm 3.5 \mathrm{~cm} / \mathrm{s}$, 血流量 $1.6 \pm 0.6 \mathrm{ml} / \mathrm{s}$, 血管 径 $4.6 \pm 0.5 \mathrm{~mm}$, 総頸動脈については血流速度 $31.5 \pm 5.2 \mathrm{~cm} / \mathrm{s}$, 血流量 $14.0 \pm 3.2 \mathrm{ml} / \mathrm{s}$, 血管 径7.5 $00.6 \mathrm{~mm}$ であった.

2. 左右の椎骨・総頸動脈血流に有意な差は みられなかったが, 椎骨動脈血流速度は左がや や速かった。

3. 椎骨・総頸動脈血流速度には性差はみら れなかったが, 総頸動脈の血流量, 血管径およ び血管径の左右差指数は男性が有意に值が大き かった。

4. 総頸動脈血流速度は加齢と共に有意に遅 くなるが，椎骨動脈血流速度は速くなる傾向に あり，血管によって加㱓变化に差がみられた。 また総頸動脈血管径は加齢と共に太くなるが, 
総頸動脈血流量はほとんど加㱓変化がなかった.

5. 椎骨・総頸動脈血流の左右差指数には有 意な加㱓変化はみられなかった。

6. 椎骨動脈血管径の測定は困難な場合が少 なくなく，椎骨動脈の血管径と血流量の測定上 の不確実性は, 超音波ドップラー法の問題点で あると思われた。

7. 以上より超音波ドップラー法による椎骨 ・総頸動脈血流の測定には, その絶対値よりも 左右差や経時変化に意義があるように思われた。

\section{参考文献}

1）康勲, 和田佳郎, 松永 喬, 他: 当科 10 年 間におけるめむい外来受診患者の統計的観察. 耳鼻臨床 補37：51〜 58, 1990.

2）津田 守：めまい患者における椎骨動脈血流動 態及びその修飾因子について。目鼻 $89: 886$ $\sim 898,1986$.

3）神田 直：椎骨脳底動脈不全とめまい, 循環科 学 $5: 958 \sim 962,1985$.

4）佐野光仁, 松永 亨: 総頸動脈および椎骨動脈 血流速度の記録一Doppler 法による一. 耳喉 $48:$ 143 148, 1976.

5）松永 亨, 松永 喬, 内藤 㩦, 他：椎骨動脈 血流とめまい.平衡障害についての考察. 日耳 鼻 $80: 139 \sim 144,1977$.

6）松永亭, 荻野仁: 椎骨脳底動脈疾患. JOHNS 4 : 951 958, 1988.

7）松永 亨：血流測定装置. 耳喉 $53: 853 \sim 859$, 1981.

8) Keller HM, Meier WE and Kumpe DA : Noninvasive angiography for the diagnosis of vertebral artery disease using doppler ultrasound (vertebral artery doppler). Stroke $7: 364$ $\sim 369,1976$.

9）吉村正蔵, 古幡 博, 広田秀美, 他：内頸 - 外 頸動脈および椎骨動脈血流量の超音波による無 侵襲的定量法の開発. 脈管学 $22: 191 \sim 198$, 1982.

10）米田正太郎：超音波測定法. 総合臨床 32 ： 2507 2513, 1983.

11）松永 喬, 川本浩康, 内藤 鹪, 他：めまい患 者と超音波椎骨動脈血流検査法 (Doppler 法) —モデル実験との対比一. 耳鬾臨床 $67: 763 \sim$
$774,1974$.

12）稲岡 長：超音波ドプラ法による脳血管障害の 局所診断. 大阪大学医学雑誌 $30: 223 \sim 239$, 1978.

13）金子仁郎，稲岡 長，白石純三：超音波 Doppler 血流検查法の臨床応用. 最新医学 29： 1290 1298, 1974.

14）松永 亨, 後藤和彦：血流測定装置. 耳鼻咽喉 科診療 (堤 昌巳編). 363/2-3, 六法出版, 東京, 1980 .

15）和田佳郎, 藤田信哉, 康勲, 他 : めまい患 者の椎骨・総頸動脈に及ぼす脳循環改善剤の影 響一超音波ドップラー法による一。耳鼻臨床 補37 : 78〜83, 1990.

16）亀山正邦：脳底部動脈 Variation 9 臨床病理学 的意義. 神経進歩 5:758 767, 1961.

17）樫原道治：頸動脈の硬化度一本邦之欧米との差 一. 診断と治療 $75: 1760 \sim 1762,1987$.

18）吉村正蔵, 小原 誠, 菅野亮一: 脈波之動脈硬 化. 日本臨床 $38: 3235 \sim 3246,1980$.

19）澤井冬樹：脳萎縮と脳循環（第 2 報）一加路々 総頸動脈血流動態一. 奈良医学雑誌 38 : 980 989, 1987.

20）後藤 昇 : 脳血管の解剖一血管障害の理解のた めに一. 49頁, メディカルトリビューン, 東京, 1987.

21) Inamori $T$, Machizuka $H$, Takayasu $Y$, et al : Intravenous digital subtraction angiography for patients with positional nystagmus. Auris Nasus Larynx (Tokyo) $13:$ 113 121, 1986.

22）鈴村滋生, 藤田信哉, 松永 喬 : めまい疾患と IVDSA 所見一57例の臨床統計より一. 耳鼻臨 床補37 : 107 113, 1990 .

23）藤田信哉, 和田佳郎, 鈴村滋生, 他 : 良性発作 性頭位眩莗症における DSA および Doppler 法 の所見. 耳鼾臨床 補37 : 84 91, 1990.

24）宮崎 学：ドップラー法. Clinical neuroscience $6: 752 \sim 753,1988$.

25）吉田茂：超音波ドプラ法. 日本臨床 $43: 290$ $\sim 298,1985$.

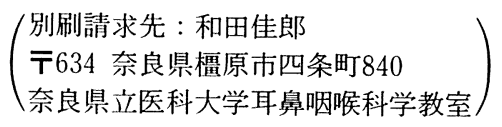

